\title{
ENTRY COSTS AND QUALITY OF BUSINESS ENVIRONMENT: A CRITICAL ANALYSIS ${ }^{I}$
}

\section{CUSTOS DE ABERTURA DE EMPRESAS E QUALIDADE DO AMBIENTE DE NEGÓCIOS: UMA ANÁLISE CRÍTICA}

Doutor em Economia pelo Departamento de Economia da North Carolina State University. Professor titular do Departamento de Administração da Universidade de São Paulo (USP). Avenida Professor Luciano Gualberto, 908, sala C-18, Cidade Universitária, São Paulo - SP - Brasil - CEP 05508-900 E-mail: dezylber@usp.br

This paper was prepared for the Conference on Transaction Costs organized by the Ronald Coase Institute. Chicago, USA. The author acknowledges the comments made by Mary Shirley, Lee Benham, Phillip Keefer and Yoram Barzel. This study is part of a project granted by the Brazilian National Scientific Research Council-CNPq. The author is solely responsible for the contents. 


\section{ABSTRACT}

Transaction costs are the costs to protect property rights. Institutions are shaped in order to control transaction costs in society. Studies have been developed to measure transaction costs both at the macro and microeconomic levels. Entry costs, i.e., the cost to start up a new business are considered a proxy for business environment quality, being also interpreted as a proxy to transaction cost measurement. This paper presents new elements in order to amplify the potential of research in business environment, particularly business entry costs. It stresses the limitation related to two theoretical points: first, the near decomposability of one complex transaction, and second, the complementarity between ex-ante and ex-post transaction costs, both related to the methodology adopted to measure business entrance costs.

\section{KEYWORDS}

Entry costs measurement; Ex-ante and ex-post transaction costs; Transaction costs; Start up costs; Business environment.

\section{RESUMO}

Custos de transação referem-se aos custos de proteger direitos de propriedade, e as instituições são desenhadas de modo a controlar os custos de transação na sociedade. Alguns estudos têm sido desenvolvidos para medir custos de transação tanto no nível macro como no microeconômico. Custos de abertura de empresas são utilizados como uma proxy para avaliar o ambiente de negócios, a qual é interpretada por alguns como uma medida de custos de transação. Este artigo apresenta novos elementos que ampliam o potencial de pesquisa sobre ambiente de negócios, ressaltando duas limitações existentes na literatura, a saber: a análise de transações complexas e a complementariedade entre custos ex ante e custos ex post, ambos relacionados com a metodologia adotada para medir custos de abertura de empresas. 


\section{PALAVRAS-CHAVE}

Mensuração de Custos de entrada, Custos de Transação ex ante e ex-post, Custos de Transação, Custo de abertura de empresas, Ambiente de negócios.

\section{INTRODUCTION}

High entry cost of firms in markets is seen as a signal of poor business environment (DJANKOV et al., 2002). This paper places a critical view on this approach based on the concept of substitution between ex-ante and ex-post transaction costs and near decomposable transaction dimensions. The paper also discusses the relation between entry costs and transaction costs.

The literature of transaction cost economics has shown consistent progress both in theory and empirical application. Several literature reviews have been published, as in Shelanski and Klein (I995), David and Han (2004), Marher and Richman (2008), and Ruester (20I0) giving support to the point stressed by Williamson (2000), that transaction cost economics is a case of empiric success. Hypothesis testing has been applied to almost every branch of economic activity. Strong evidences have been raised both at the microeconomic level applied to efficient institutional arrangements, as well as at the macroeconomic level, applied to institutional change. Research results are keen on showing the relevance of distinct dimensions of transaction cost analysis such as: the origin of transaction costs, transaction costs economizing as a motivation for strategic arrangements (governance mechanisms), enforcement of property rights, transaction costs reduction mechanisms, and institutional change, among others.

In spite of the relevance of transaction cost analysis our knowledge about its measurement received very superficial attention. The questions of whether transaction cost measurement is necessary and feasible, deserves further discussion. The apparently simple question of how actually to measure transaction costs has not yet found an answer suggesting the need to further develop the concept. Measuring transaction costs has proven to be more difficult than testing the alignment hypothesis of governance mechanisms at the micro level or institutional changes at the macro level.

The methodological problem of measuring transaction costs is the motivation of this paper. It raises useful elements that contribute to deepen the understanding and limitations of methodologies to measure transaction costs, particularly the potential relations between ex-ante and ex-post transaction costs. This is the basic contribution of the present paper which is structured in five parts. In the 
second it discusses the concept of transactions and transaction costs in its multidimensional structure, in the third part the approaches to transaction cost measurement are discussed, and in the fourth part an amplification of methodology is suggested. Part five concludes this study.

\section{TRANSACTIONS EVERYWHERE}

As stated by Coase (I998), transaction costs play a crucial role in determining how rights are allocated in the economy. Therefore, in dealing with measurement of costs of transaction the relevant aspect to recognize is that what is transacted is not a good or an object, but instead its dimensions in the form of complex bundles of rights. Transaction costs, therefore, are the costs associated to the protection of property rights (BARZEL, I997).

Prior to checking alternative concepts to transaction costs, it is useful to define transaction itself. As proposed by Williamson (I985), a transaction is a transfer of a good or service across technologically separable interfaces. One stage of activity terminates and another begins. Therefore, the author reduces the transaction to the exchange of goods related to the production effort, or to the technological sequence of production interface. This view can be augmented by introducing the transfer of rights associated to multiple dimensions of transactions in general. Protecting property rights and transaction costs are associated with easiness to carry transactions.

An alternative definition is proposed by Arrow (1969), "transaction costs are the costs of running the economic system." Digging in the literature of economics of organization one can find an abundance of definitions for transaction costs. For instance, Eggertsson (I990, p. I4.) defines transaction costs as "the costs that arise when individuals exchange ownership rights to economics assets and enforce their exclusive rights." The author distinguishes information costs and transaction costs, being the first eligible to be considered a transaction cost under specific circumstances, i.e., in the case of exchange of property rights.

Taking into consideration that rights are traded instead of goods, one should pay attention to the multiple dimensions of rights present in one single transaction. So, Eggertsson (I990, p. 25) explores this aspect stating that: "In a full-information world, all margins of a commodity can be measured and priced without cost, and it is therefore understandable that standard economic theory has ignored multiple qualitative dimensions."

The author points to the fact that New Institutional Economics main contribution to the economic literature is the addition of the structure of property 
rights and transaction costs. However this is followed by an increase in the complexity of the analysis.

Another definition provided by North (I990), states that: "the costs of transacting consist of the costs of measuring the valuable attributes of what is being exchanged and the costs of protecting rights and policing and enforcing agreements." The author considers transaction costs as part of costs of production, expanding therefore the neoclassical definition.

Barzel (I997, p. 4-5) discusses both property rights and transaction costs. He considers first that the concept of property rights is closely related to that of transaction costs. He defines transaction costs as the costs associated with the transfer, capture, and protection of rights. The author explores the characteristics of transaction costs questioning about the factors that prevent people from realizing the full value of their assets. His answer to this question is that commodities have many attributes whose levels vary from one specimen to another. Measuring these levels is too costly to be comprehensive or entirely accurate.

For our purposes Barzel (I997) not only opens room to the ex-ante and expost dimensions of transactions, but also adds the relevance of the measurement costs of the many attributes of a particular transaction.

The contribution of Furubotn and Richter (2000) placed the issue on a broader scope than Williamson (I985) did. Considering cognitive limitations of decision makers and considering that transactions are made between imperfect economic agents, the authors propose a broader definition of transaction including such activities as transfer of knowledge or information in connection with research and development.

They also connect the concept of transaction costs to the costs of using and adapting the institutional environment. To enrich the classification of transaction costs, in addition to the ex-ante and ex-post views, they added market, managerial, fixed, variable, and political transaction costs. Market transaction costs are related to the costs of using markets as analyzed by Coase (1998), managerial costs arise within the firms, as seen by Williamson (1996) in the literature of vertical integration and the political costs are related to institutional change, as treated by North (I990).

In summary, one can state that: First, transactions are complex mechanisms of exchange of property rights. Second, transactions have multiple dimensions - or margins, as stated by Eggertsson (I990) - and are bounded by a set of formal and informal norms. Third, one can consider as transactions, subject to measurement of costs, every change in property rights of tangible or intangible productive resources. Some examples are: a transaction between the entrepreneur and a regulatory government agent to obtain a license to operate formally; a transaction to obtain an intellectual property right over a genetic resource or a transaction between two 
governments to obtain the right to access the market. Likewise are the transactions of rights to obtain access to preferential credit offered by the government to small farmers, and a transaction between two specialized agents to organize the production of a good within a complex hybrid contractual form.

If we want to measure transaction costs, there are plenty of examples to be studied, the difficulty being to reduce a complex transaction into its measurable margins, controlling for the institutional environment.

\section{MEASURING TRANSACTION COSTS}

There are particularities of transactions that are neglected in the literature and are relevant to the present study, namely: ex-ante or ex-post dimensions, and market, managerial, and political transactions. I add that the literature of direct measurement of transaction costs is focused predominantly on private-public transactions of unregulated sectors, as are the cases of transacting rights to start up a new business. However, other transactions are relevant to be studied, whether in regulated sectors such as environmental licenses, and private-private transactions as well. An example of private-private transactions is found in the literature of strategy and intellectual property rights, where private firms consider the high ex-post monitoring costs in countries with loose property enforcement institutions. Also public-public transactions provide cases for study, such as the WTO negotiations for reducing trade barriers in the agricultural sector, where cases show that decisions related to market access are not always implemented.

The literature of transaction costs measurement has at least two main branches. The measurement of aggregated transaction costs as developed by Wallis and North (1986) is an example. The second branch is the direct measurement of transaction costs. The approach of direct measurement is based in the choice of one or more transaction dimensions followed by the measurement of costs associated with it. The time spent to start up a company or the cost to access a public service, are examples of this approach. Empirical examples can be found in Benham and Benham (1998), Gancheva (2000), Djankov, La Porta and Silanes (200I), Zylbersztajn and Graça (2003) and De Soto (2000).

Both branches are distinct from the transaction costs literature related to the alignment hypothesis under which agents choose governance architectures that economize in transaction costs, which is predominantly discussed in the literature of strategy and economics of organizations as related with the work of Oliver Williamson (1985, 1996). To test the alignment hypothesis, it is not actually necessary to measure transaction costs, but to contrast the performance 
of alternative governance modes considering the transactions characteristics ${ }^{2}$. Similarly at the macroeconomic level the use of the concept is directed to the hypothesis of the logic of institutional change and the reduction of transaction costs.

\section{EX-ANTE AND EX-POST TRANSACTION COSTS}

Consider the question of why should one be worried about actually measuring transaction costs. One answer might be for the understanding and implementation of market augmenting institutional changes. This motivation relies on the effect that the institutional environment has on transaction costs, the definition and enforcement of property rights being the most important. This purpose fits into the literature of development and the purposes of public agents, development banks and international agencies.

Other incentive to measure transaction costs relates to strategic design. A collection of private agents might be interested in designing joint strategies in order to augment their efficiency in the market. If the players have an idea of the effects of specific institutional arrangements in enhancing their collective competitive power, they have incentives to build transaction costs reducing mechanisms. This purpose resembles Williamson's governance mechanism choice and adopts an efficiency perspective.

Let's return to the basic objective of this paper, namely the measurement of transaction costs. The key obstacle found in attempts to measure actual transaction costs based on the definition of single transactions is that transactions are never simple, but are embedded in the social tissue where they take place. Therefore, to isolate one single dimension from a phenomenon that is multi-dimensional in nature is an intervention that at least should be recognized and followed by coeteris paribus assumptions.

The isolation of one or a couple of margins of a complex mechanism must consider the effects of the variables not being measured and its interaction, either because they are too difficult to measure or due to the fact that we ignore their existence. The concept is related to Herbert Simon's (I962) "near decomposable system" defined as any system where the short run behavior of each component is approximately independent of the other components.

Similar rational applies to the consumer demand theory, where one does not need to measure utility in order to estimate a demand function. 
Being the purpose to provide comparable measures of costs of transaction, then the problem is magnified. When one chooses one measurable aspect, which is part of a complex system, and use it to compare different countries or even regions in the same country, then we are only apparently contrasting similar things. I propose that in non near decomposable systems, "the isolated margin of a complex transaction removed from the entire governance mechanism of support might not provide the same and comparable measure."

A second simplification is the focus on ex-ante costs of transaction, ignoring potentially relevant interactions with ex-post transaction costs. In doing that not only relevant aspects are ignored but also a methodological bias is introduced, since some governance mechanisms are built ex-ante in order to protect agents from ex-post transaction costs. The sum of both transaction costs is the relevant measurement and choosing one isolated margin introduces a potential source of bias. This is largely ignored in the literature about start-up costs.

Two examples can illustrate the problem. The first is the individual that applies for a club membership. His personal history and profile must be evaluated prior to his acceptance and reputation mechanisms are considered. If measured in isolation this might be interpreted as ex-ante costs of transaction to obtain a membership right, however, it is built to avoid ex-post transaction costs, with the expected minimization of the total costs. A second example is the risk analysis made by the bank in order to contract for credit. The bank incurs in a cost previously to contract in order to reduce the risk of default. Therefore the total transaction cost might be smaller than the alternative arrangement that precludes the previous analysis.

Simplification of procedures are suggested in studies of costs to start new business, where the time to obtain a license is interpreted as a measure of business environment quality. I claim that high entrance costs do not necessarily mean high transaction costs or a bad business environment not only because it might be economizing in ex-post hazards but also because complex procedures might be necessary to control and regulate the economic agents. The correct contrast should be done with the costs of the feasible alternative.

So, how to proceed? One answer is aligned with the perception that property rights and transaction costs are on the foundations of new institutional economics, but by no means are compatible with less complex methodologies than the offered by other branches of economics. Identifying the limits of the methodological approach is the first step to amplifying the analytical capacity of existing tools, being the case of my argument.

In the present case I consider that the observation of the entirety of complex governance mechanisms behind the transaction cost measurement under study is the limitation number one. Number two is the preoccupation with near decom- 
posability conditions, especially when dealing with formal and informal rules that affect the governance structure where specific transactions are placed. This gains relevance when dealing with international contrasts of transaction cost measurements. The third limitation is the existence of tradeoffs between ex-ante and expost transaction costs. If ignored, the resulting measurements might be partial or irrelevant.

The choice of a particular transaction, as opening a new firm, as the object of study to compare international experiences should consider some elements:

- The choice of the same transaction is as important as the control for the institutional environment. The same measurable characteristic of a complex transaction, once removed from the institutional environment where it is placed, might no longer be comparable.

- The choice of an unregulated sector is a good starting point in the literature about entry costs measurement but regulated sectors are also good cases to be approached.

- Apparently complex transactions might offer interesting opportunities for study, if institutional environment is controlled. The example of the transaction between government and small farmers to obtain credit might fit this situation.

- The study of the same transaction over time offers another case. Likewise, the analysis of incentives for changes in the institutional environment is the most important, but private arrangements should not be ignored.

\section{CONCLUSIONS}

The contribution of the literature about measuring transaction costs is largely recognized as a proxy to business environment measurement, but it should avoid falling in the trap of presenting transaction costs approach as a panacea. Providing tautological explanations of the range of problems that the new institutional economics can approach does not help to identify the challenges needed to progress with the instruments to measure costs of transaction.

Deepening the studies on standard measurements is a promising line of research. It seems that small industries are a good case of studies that should be classified as entry costs instead of transaction costs. Some entry costs are costs related to protection of property rights, therefore, are costs of transaction. Choosing one simple case to start from facilitates the development of research, but by no means represents a boundary for the methodology. In order to advance 
for more complex transactions, the control of institutions seems to be a crucial step, especially if we want to compare different countries.

Other transactions of a seemingly more complex nature are important for specific countries, and should be studied if there are good prospects of impacts on transaction cost reducing institutional changes. Following changes of transaction costs over time is a desirable line of study, since it allows the control for changes in institutions and their effects over time.

The limitation pointed in this study, namely the removal of a single transaction from the governance environment where it occurs, deserves further discussion since it might highlight the limitations for international contrasts, as carried in several studies by the World Bank. The focus on ex-ante costs and the existence of ex-ante and ex-post tradeoffs is another limitation that this paper suggests to be considered. Among all the incentives for the direct trials of measuring transaction costs, market augmenting institutional changes ought to play a dominant role.

\section{REFERENCES}

ARROW, K. The economics of agency. In: PRATT, J. W.; ZECKHAUSER, R. J. (Ed.). Principals and agents: the structure of business. Boston: Harvard Business School Press, I985 p. 37-5I.

BARZEL, Y. Economic analysis of property rights. 2. ed. Cambridge: Cambridge University Press, I997.

BENHAM, A.; BENHAM, L. Measuring the costs of exchange. In: ANNUAL CONFERENCE OF THE INTERNATIONAL SOCIETY FOR THE NEW INSTITUTIONAL ECONOMICS, 2., I998, Paris. Annals... Paris: International Society for the New Institutional Economics, I998.

COASE, R. H. The firm, the market and the law. Chicago: The University of Chicago Press, I998.

DAVID, R; HAN, S. A. A systematic assessment of empirical support for transaction cost economics. Strategic Management Journal, Chicago, v. 25, Issue I, p. 39-58, 2004.

DE SOTO, H. The mistery of capital. New York: Basic Books, 2000.

DJANKOV, S.; LA PORTA, R.; SILANES, F. L. The regulation of entry. Policy research working paper, v. 266I, 200I.

DJANKOV, S. et al. The regulation of entry. The Quarterly Journal of Economics, Cambridge, v. CXVII, Feb. 2002.

EGGERTSSON, T. Economic behavior and institutions. Cambridge Surveys of Economic Literature. Cambridge: Cambridge University Press, I990.

FURUBOTN, E. G.; RICHTER, R. Institutions and economic theory: the contributions of the New Institutional Economics. Michigan: The University of Michigan Press, 2000.

GANCHEVA, Y. Rules and transaction costs in transition. Bulgaria: Institute for Market Economics, 2000.

MARHER, J; RICHMAN, B. Transaction cost economics: an assessment of empirical research in the social sciences. Business and Politics, Berkeley, v. Io, n. I, p. I-63, 2008. 
NORTH, D. C. Institutions, institutional change and economic performance. Cambridge: Cambridge University Press, I990.

RUESTER, S. Recent developments in transaction cost economics. Resource Markets Working Papers, v. I8, 20I0. Disponível em: http://www.sophia-ruester.de/files/paper_TCE.pdf. Acesso em: I7 out. 20IO.

SHELANSKI, H. A; KLEIN, P. G. Empirical research in transaction cost economics: a review and assessment. Journal of Law, Economics and Organization, Oxford, v. II, n. 2, p. 335, I995.

SIMON, H. The architecture of complexity. Proceedings of the American Philosophical Society, Philadelphia, v. ıо6, n. 6, Dec. I962.

WALLIS, J. J.; DOUGLASS C. N. Measuring the transaction sector in the American economy. In: ENGERMAN, S. L.; GALLMAN, R. E. (Ed.). Long term factors in American economic growth. Chicago: University of Chicago Press, I986.

WILLIAMSON, O. E. The economic institutions of capitalism. New York: Free Press, I985. The mechanisms of governance. Oxford: Oxford University Press, I996.

. The new institutional economics: taking stock, looking ahead. Journal of Economic Literature, Pittsburgh, v. XXXVIII, p. 595-6I3, Sept. 2000.

ZYLBERSZTAJN, D.; GRAÇA, C. T. Costos de formalización de las empresas: medición de los costos de transación em Brasil. Revista de Economia Institucional, Bogotá, v. 5, n. 9, p. I46-I65, 2003. 